V. Fedorovych, Y. Ostroverkh,

N. Kozakova, Kharkiv, Ukraine

\title{
THE METHODOLOGY OF SHARPENING OF BLADE TOOLS MADE OF SUPERHARD MATERIALS
}

\begin{abstract}
High durability of the blade tool from superhard materials (SHM), which have unique physical and mechanical properties, creates the prerequisites for its effective use in automated production. However, the widespread use of such tools is constrained by its relatively low reliability during operation. This disadvantage is due to the imperfection of the processes of obtaining SHM: the presence in it residual stresses, internal defects, which appear even after sharpening and thermo-activated finishing. The processes of sharpening of tool blade from superhard materials and cutting with this tool are characterized by high levels of contact pressures and temperatures in the treatment area. Therefore, it seems inappropriate to choose sparing conditions for its sharpening and refinement to ensure the defect of these processes. In connection with this, a new methodological approach is proposed, which makes it possible to determine the cutting conditions and other conditions for sharpening and finishing the SHM blade tool, in which material defects are revealed even at the tool manufacturing stage. To this end, in the software packages COSMOS, ANSYS, NOSTRAN, Third Wave AdvantEdge, thermo-force stress in the cutting edge of the tool simulated under extreme conditions while its operation. This simulations are the initial data for solving the inverse problem - finding conditions (speed, cross feed, normal pressure in the contact) and other diamond grinding modes (physical and mechanical properties of the bond and diamond grains of the wheel, grain size and concentration) according to the wellknown stress-strain state cutter from SHM in extreme conditions of its operation. The proposed methodology allows rejecting defective cutters at the stage of their manufacture, thereby increasing the reliability of operation of blade tool from superhard materials.
\end{abstract}

Keywords: blade tool from SHM; defects in the internal structure; sharpening and finishing; tool reliability; extreme operating conditions; stress-strain state; diamond grain; grinding conditions.

Use of blade and abrasive tools from superhard materials (SHM) is hampered by a number of objective reasons. For a blade, it is a relatively low reliability of its operation and laboriousness of sharpening and regrinding, and for an abrasive it is a low utilization rate of expensive diamond grains and, as a result, a high cost of processing. Tools equipped with superhard materials, providing high performance and quality of processing difficult-to-cut materials, make it possible in some cases to replace the grinding operation with turning and milling. The wide-range SHM blade tools produced today have high hardness and wear resistance under conditions of elevated pressures and temperatures occurring during processing of various materials, however, they are distinguished by a wide range of strength characteristics [1]. Therefore, the productivity of machining with such tool is often limited by the fragile 
destruction of its cutting part in the form of flaking and chipping [2]. Flaking of small particles of the cutting edge as an intra-contact type of destruction that does not extend beyond the contact of the chip with the front surface is caused by defects in the tool material and residual stresses in it. Chips, manifested in the separation of a relatively large volume of the cutting part of the tool, occur when the maximum loads and temperatures are exceeded. The cause of these failures is in most cases the operation of the tool under conditions of significant fluctuations of the loads due to changes in the thickness of cutting and allowance, the random nature of the processes affecting the formation of contact zones, the instability of the properties of the processed and tool materials. The last factor for SHM is primarily due to defects in the internal structure associated with the imperfection of the processes of their synthesis, surface defects and residual stresses resulting from their manufacture or subsequent processing of the tool and collectively manifested in reducing the strength of the cutting part. The presence of these factors determines the failures in the operation of the cutting tool of the SHM and reduces its reliability. Considering that, the advantages of tools equipped with an SHM in terms of productivity and processing quality are maximally realized in automated production conditions on numerically controlled machines, processing centers, flexible production modules and systems [3]. The requirements for their performance and reliability increase especially due to the need to ensure trouble-free operation of expensive and high-performance equipment.

Improving the technology of synthesis of superhard materials and solution of material science problems associated with the creation of more durable, thermal and wear-resistant SHM, partially solve this problem. However, its solution cannot be considered outside the context of cutting conditions (processing material, cutting conditions, tool geometry), which largely determine the possibility of tool destruction. According to the data of [4], the probability of destruction of cutting tools from SHM, even with finishing turning, can reach $47 \%$. In some cases, these tools are used for roughing (at depths of up to $4 \mathrm{~mm}$ ), the same tool can be used in both finishing and roughing operations, ensuring the necessary productivity and quality of processing. Authors [4] reasonably associate reliability with limiting stresses on the front and rear edges of the cutter during cutting. Using probabilistic calculation methods, they take into account the influence of only a force factor on the destruction of an SHM, but do not consider the effect of temperature in the cutting zone. However, temperature effects also have a significant effect on the cutting part of the tool during the entire time of contact of the cutter with 
the part, and the formation of microcracks on the surface of the SHM may be due to the action of one or several mechanisms of destruction. And if force loading is due to the presence and nature of loads, conditions for cutting-in and exiting tool from the workpiece, the level and ratio of the static and dynamic components of the cutting force, tool wear dynamics over the durability period [5], then thermal is the anisotropy of the thermophysical properties of SHM crystallites, significant difference in coefficients of thermal expansion of diamond crystallites and catalyst metal inclusions remaining in the SHM after synthesis.

Thus, under the influence of thermo-force loading during blade processing, a non-uniform stress-strain state (SSS) of both processed and instrumental materials arises, which can activate certain mechanisms of destruction of the contacting surfaces. For example, for SHM, this can be the oxidation of inter- and intracrystalline inclusions, the migration of a metal catalyst to the surface [6], resulting in chipping of the cutting edges of the tool, the formation of a grid of microcracks on the surface and macro-cracking of SHM. Therefore, during sharpening, used sparing grinding conditions under which no similar micro- and macro-changes would occur in the structure of the SHM. Visual inspection after such sharpening and finishing does not guarantee the reliability of the tool, and its failure and failure may occur when the tool is working, and the manufacturer does not guarantee the operation of such a tool in more severe conditions of its operation.

To reduce the operational failures of the SHM blade tool, a new methodological approach is proposed, which makes it possible to ensure the reliability of such a tool already at the stage of its sharpening and thermoactivated finishing. For this purpose, it is advisable to carry out sharpening and fine-tuning of the blade tool at thermal power loads close to the conditions of its subsequent operation, i.e., characterized by the presence of high pressures and temperatures in the grinding zone (when sharpened), the same as in the cutting zone (at operation of the tool SHM). Thus, it is proposed to sharpen and bring the SHM blade tools in such thermal-force conditions so that the defects obtained during the synthesis of the SHM manifest themselves before the operation of the tool, and the rejection would be carried out at the manufacturing stage.

The following algorithm is proposed for the implementation of this approach, based on 3D modeling of the stress-strain state. At the first stage, for cutting with the help of a package of applied programs using the finite-element 
method, the limiting thermal stress in the cutting edge of the tool under extreme conditions of its operation are calculated (Fig. 1).

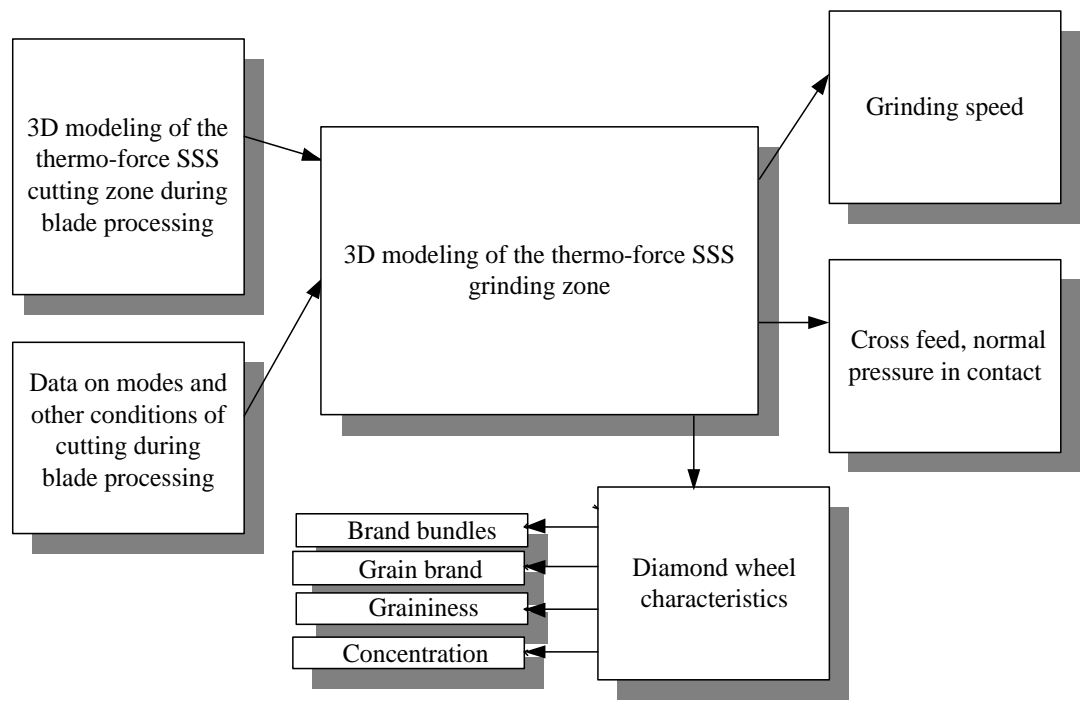

Figure 1 - Algorithm for determining the sharpening coditions of the SHM blade tool

The initial data for this can be the calculated values of the forces and temperatures characterizing the conditions of processing of specific materials by the SHM blade tool. The three-dimensional model of the blade tool can also be loaded with cutting conditions on which this tool works in extreme conditions of operation, with the physicomechanical properties of the tool and processing materials. It is possible to determine three-dimensional operational stresses in superhard tool material using application packages COSMOS, ANSYS, NOSTRAN, designed for research calculations using the finite element method [7-10], which (in a universal configuration) allow us to determine displacements, strains and stresses at static and dynamic effects; determine stress-strain states: physically and geometrically non-linear models, when deformable solids contact, if there are cracks; stationary and nonstationary nonlinear thermal processes; determine the sensitivity of the results of all types of analysis to changes in the properties of system elements; implement multi-criteria optimization with simultaneous use of different types of constraints and adaptive stress analysis. 
Thermal 3D SSS with blade processing of various materials is even more efficient to calculate by modeling the cutting process in the software package "Third Wave AdvantEdge", specialized for blade processing. The initial data for calculating stresses in this package are physicomechanical roperties of the superhard tool and processing materials, as well as the corresponding specific turning operation modes and geometrical parameters of the blade tool. At the same time, "Third Wave AdvantEdge" in the automated mode determines and analyzes the dynamics of changes in the stress-strain state of the "cutter-part" system for various conditions of its operation. An example of the calculation of stresses and temperatures in the cutting zone of copper is shown in Figure 2.

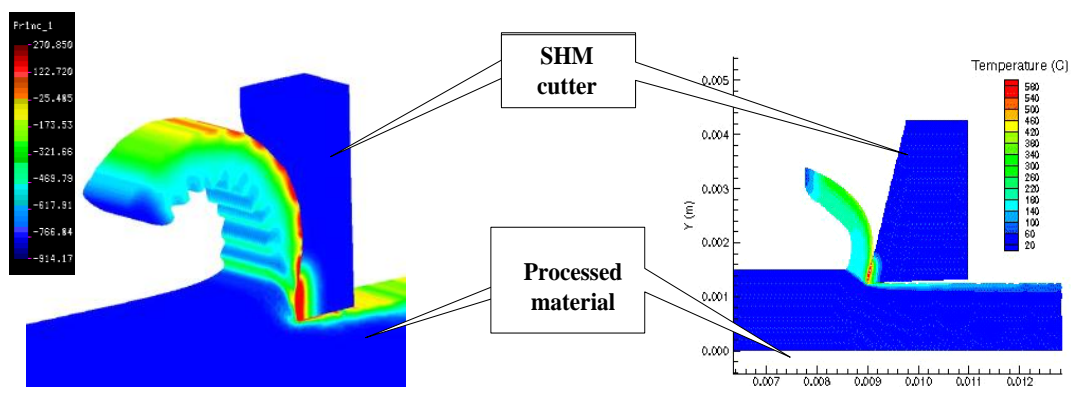

a)

б)

Figure $2-3 \mathrm{D}$ model of the process of blade processing and the results of the calculation of stresses (a) and temperature in the cutting zone (b)

Thus obtained values of thermal stress in the cutting edge of the cutter under extreme turning conditions are the source data for solving the inverse problem - modeling the stress-strain state of the blade tool when it is sharpened and found, based on it, modes and other conditions of grinding and heat activated finishing. Thus, recommended conditions for sharpening and finishing blade tools from different types of SHM can be obtained for specific conditions of turning with this tool.

The use of COSMOS, ANSYS, NOSTRAN packages for this allows us to simulate the energy and strain density in three dimensions, using which, using Griffiths theory, we can determine the possibility of formation and development of microcracks on the surface and inside the SHM (Fig. 3). In the course of solving the inverse problem, the grinding speed, lateral flow, normal pressure in contact for specific physico-mechanical properties of grinding 
SHM, as well as wheel characteristics (diamond grade, bond, grain size and concentration), which provide thermal stress, are determined by the known level of operating thermal stress. In the cutting edge, when it is sharpened, slightly higher than the thermal-stresses during blade processing (Fig. 1). This will ensure the opening of defects of the superhard cutter material during its sharpening: if it is not able to withstand such thermal stress, the cutter will be rejected at the stage of its manufacture, and not during operation.
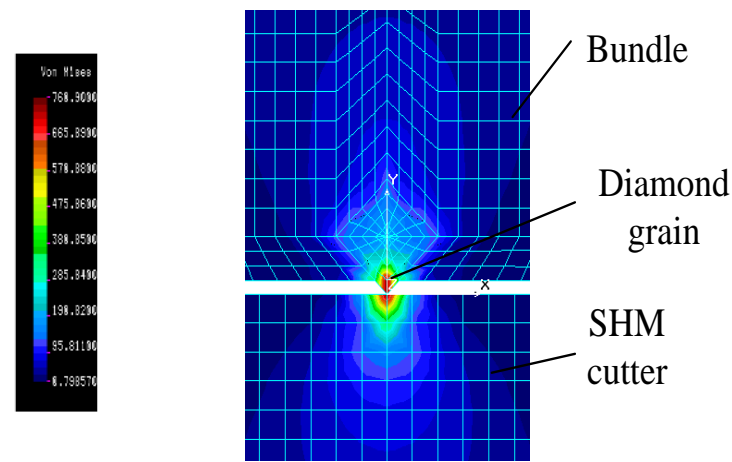

Figure 3 - The stress-strain state of the SHM during sharpening

Sharpening modes and other diamond grinding conditions obtained during the solution of the inverse problem will ensure that thermo-force stresses exceeding the operating stresses are present in the sharpened SHM and, thus, the conditions of the sharpening and thermo-activated finishing at which the SHM defects are detected are found at the tool manufacturing stage. This will make it possible to make recommendations on the expediency of using a tool from one or another superhard material on a particular turning operation.

The process of diamond grinding of superhard materials intended for blade processing can also be analyzed by simulating a single diamond grain by micro-cutting of various processed materials in the «Third Wave AdvantEdge» package. Its use allows one to conduct model experiments on the study of microcutting of various materials with diamond grains of various geometries in various loading conditions. According to the well-known stress-strain state of SHM, arising in it under extreme conditions of its operation in the blade tool, the software package «Third Wave AdvantEdge» analyzes in dynamics its 
influence on the stress and temperature fields in the diamond grain of the grinding wheel (Fig. 4).

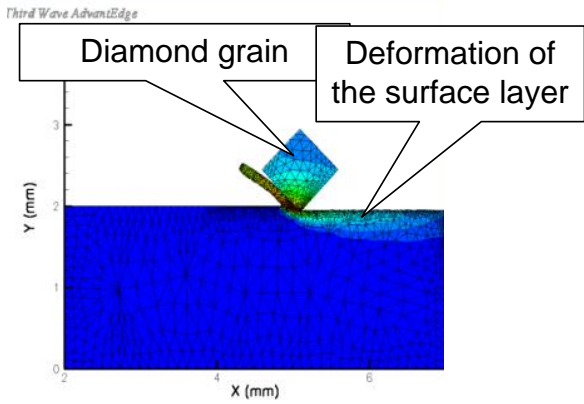

a)

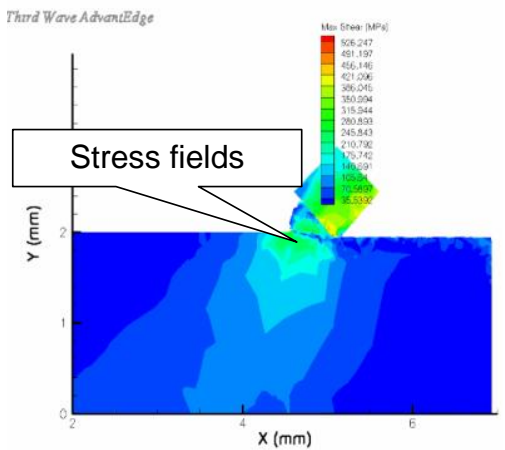

b)

Third Wave AdvantEdge

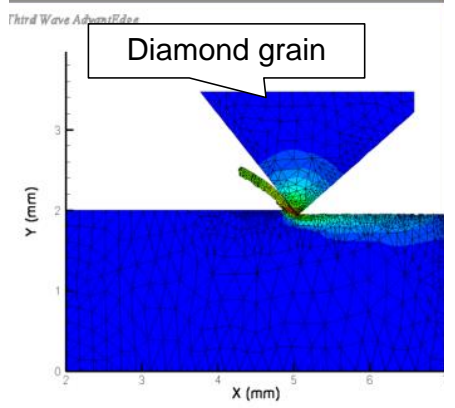

c)

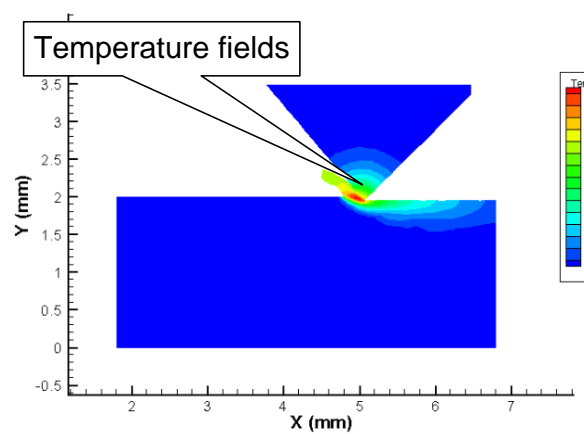

d)

Figure 4 - Modeling the process of microcutting with a single diamond grain:

a) a finite-element model of microcutting with grain with a wear area;

b) the results of the calculation of stress fields; c) finite-element model of microcutting sharp diamond grains; $d$ ) the results of the calculation of temperature fields

The subsequent computer processing of the results of the micro-cutting process simulation allows us to determine the dynamics of changes in temperatures and cutting forces (Fig. 5). 

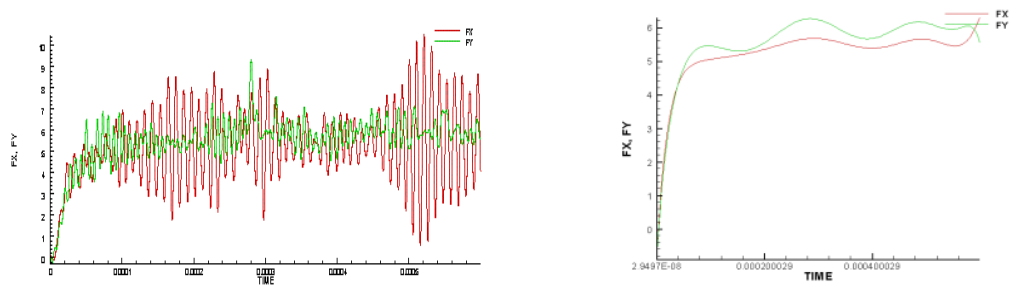

Figure 5 - Dynamics of change of normal (FY) and tangential $(\mathrm{FX})$ microcutting forces

The obtained thermal characteristics are used to solve the inverse problem - the grinding conditions for micro- and macro-destruction (self-sharpening) of diamond grains are determined by the simulated stress-strain state, which ensure the self-sharpening of the diamond grains of the grinding wheel and the opening of polished SHM defects when grinding and finishnig namely: physical and mechanical properties (grade) of bonds and diamond grains of a wheel, their sizes (granularity), concentration and grinding modes (speed, cross feed, normal pressure in the contact).

Thus, using modern application packages for the finite element method, theoretically, using calculated data on blade processing without long, laborious and expensive experiments, it is possible to determine the conditions for sharpening a blade tool with SHM, depending on its subsequent operational purpose. Combining a control operation with an "address" (for a specific use) sharpening will reduce the failures of such a tool in the specific conditions of its industrial use. The use of this approach allows us to exclude rapid tests and other measures for diagnosing a blade tool before starting its operation and, in combination with appropriate methods of control during the cutting process, significantly improve the performance of an expensive tool from SHM. The proposed methodology also allows us to expand the technological capabilities of the use of blade tools, since it allow to find the area of effective application for different quality SHMs.

References:: 1. Шульженко A. А. Поликристаллические сверхтвердые материалы в режущем инструменте // Інструментальний світ. - 1999. - № 4-5. - С. 14-16, № 6. - С. 10-12. 2. Девин Л. Н., Стахнив Н. E. Применение метода акустической эмисси для оценки работоспособности резцов из АТП при точении алюминиевых сплавов // Резание и инструмент в технологических системах. - Вып. 62. - 2002. - С. 44-47. 3. Романов В. Ф. Специальные инструменты из поликристаллических алмазов (PCD), кубического нитрида бора $(\mathrm{PCBN})$ и керамики для высокоскоростного резания деталей из черных и цветных металлов // Резание и инструмент в технологических системах. - 2002. - Вып. 63. - С. 139144. 4. Новиков Н. В., Девин Л. Н. Надежность лезвийных инструментов из ПСТМ при 
чистовом точении закаленных сталей // Сб. науч. тр. Института сверхтвердых материалов им. В.Н. Бакуля НАН Украины. Серия Г: Процессы механической обработки, станки и инструменты. - Киев, 2002. - С. 273-280. 5. Новиков Н. В., Девин Л. Н. Надежность лезвийных инструментов из ПСТМ при чистовом точении труднообрабатываемых материалов // Материалы X Междунар. науч.-техн. семинара «Высокие технологии: развитие и кадровое обеспечение», Харьков, 2000. - С. 98-100. 6. Федорович В. А., Козакова Н. В. Определение режимов и условий заточки лезвийного инструмента из сверхтвердых материалов в зависимости от его эксплуатационного назначения // Резание и инструмент в технологических системах. - 2004. - Вып. 66. - С. 203-208. 7. Huang J. M. An Evaluation of Chip Separation Criteria for the FEM Simulation of Machining / J. M. Huang, J. T. Black // Journal of Manufacturing Science and Engineering: Trans. of ASME. - 1996. Vol. 118, No 4. - PP. 545-554. 8. Zaghbani I. A thermo-mechanical coupled f.e.m model for orthogonal cutting / I. Zaghbani, W. Bouzud, K. SaI // Proceedings of the 8th CIRP International Workshop on Modeling of Machining Operations. - 2005. - PP. 139-145. 9. Markopoulos A. P., Kundrák J. FEM/AI models for the simulation of precision grinding, Manufacturing Technology, 16(2), PP. 384-390. (2016). 10. Mamalis A. G., Kundrák J., Manolakos D. E., Gyáni K., Markopoulos A. Thermal Modelling of Surface Grinding Using Implicit Finite Element Techniques // International Journal of Advanced Manufacturing Technology, 21(12), PP. 929-934. (2003).

\author{
В. Федорович, С. Островерх, Н. Козакова, Харків, Україна
}

\title{
МЕТОДОЛОГІЯ ЗАТОЧУВАННЯ ЛЕЗОВОГО ІНСТРУМЕНТА З НАДТВЕРДИХ МАТЕРІАЛІВ
}

\begin{abstract}
Анотація. Висока стійкість лезового інструмента з надтвердих матеріалів (НTM), яким притаманні унікальні фізико-механічні властивості, створюе передумови для його ефективного застосування в автоматизованому виробництві. Однак, иирокое застосування такого інструмента стримується відносно невеликою надійністю його при експлуатаиії. Цей недолік зумовлено недосконалістю процесів виробництва НТМ: наявністю у них залишкових напруг, внутрішніх дефектів, які виявляються навіть після заточування й термоактивованого доведння. Прочес заточування лезового інструмента $з$ надтвердих матеіалів і різання ичим інструментом характеризуються високими рівнями контактних тисків і температур у зоні обробоки. Тому видається некоректним вибір щадних умов його заточування й доведення для забезпеченин бездефектності даних процесів. У зв'язку із иим пропонується новий методологічний підхід, який дозволяє визначати режими й інші умови заточування і доведення інструмента з НТМ, за яких дефекти матеріала розкриваються ще на стадії виготовлення інструмента. 3 тією ж метою в пакетах прикладних програм COSMOS, ANSYS, NOSTRAN, Third Wave AdvantEdge моделюються термосилові напруги у ріжучому клині різия, що виникають в екстремальних умовах його експлуатації. Вони ж є вихідними даними для розв'язання зворотньої задачі знаходження режсимів (швидкості, подачі, нормального тиску в контакті) й інших умов алмазного шліфування (фізико-механічних властивостей зв 'язування й алмазних зерен круга, їхньої зернистості й кониентрачиії) за відомим напружено-деформованим станом різия $з$ НТМ в екстремальних умовах його експлуатації. Запропонована методологія дозволяє відбраковувати дефектні різиі ще на стадії їх виготовлення, тим самим, підвищувати надійність експлуатаиії лезового інструмента з надтвердих матеріалів

Ключові слова: лезовий інструмент з НТМ; дефекти внутрішньої будови; заточування й доведення; надійність інструмента; екстремальні умови експлуатації; напруженодеформований стан; алмазне зерно; режими шліфування.
\end{abstract}

